\title{
EFFECT OF DIETARY GARLIC (ALLIUM SATIVUM) SUPPLEMENTATION ON NILE TILAPIA OREOCHROMIS NILOTICUS JUVENILES PERFORMANCE UNDER TWO STOCKING DENISTIES
}

\author{
Hemat K. Mahmoud ${ }^{1}$ and A. M A El-Hais ${ }^{2}$ \\ ${ }^{1}$ Department of Animal Production, Faculty of Agriculture, Zagazig University, Egypt. \\ ${ }^{2}$ Department of Animal Production, Faculty of Agriculture, Tanta University, Egypt. \\ Abdelazizhais2013@yahoo.com.
}

(Received 12/1/2017, Accepted 1/3/2017)

\section{SUMMARY}

$\mathrm{T}$ his study was performed to determine the effect of different fish stocking densities (10 and 20 fish/aquarium) and garlic, Allium sativum level $(0,10$ and $20 \mathrm{~g} / \mathrm{kg}$ diet $)$ as feed additive on the growth performance, body composition and health of Nile tilapia, Oreochromis niloticus juveniles. The experimental fish with initial weight of about $5.06 \mathrm{~g}$ was fed diets contained about $30 \%$ crude protein and $429 \mathrm{kcal} / \mathrm{kg}$ diet as gross energy. The preferable increase of final weight, daily weight gain, specific growth rate, survival rate and feed utilization were obtained by garlic supplementation at $20 \mathrm{~g} / \mathrm{kg}$ diet. Survival rate was not influenced by fish stocking density. The higher body composition as crude protein with moderate ether extract were observed with low density rate of rearing fish fed diets supplemented with $10 \mathrm{~g} / \mathrm{kg}$ diet of garlic. Heamatological indices explained no hazard effects of both of stocking rate and garlic supplementation on health and liver activity of experimental fish. In general, there were slight differences among both of stocking densities on growth performance, body composition and blood parameters of Nile tilapia juveniles especially with a garlic supplementation. So, it could be concluded that garlic, Allium sativum may be used to enhance the health and growth performance with high stocking rate of Nile tilapia, Oreochromis niloticus fish.

Keywords: Garlic, stocking density, Nile tilapia, growth, carcass, hematological parameters

\section{INTRODUCTION}

Tilapia (Oreochromis niloticus) is one of important and economical freshwater fish that are rearing widely and it is considered one of the most commonly produced fish after carp and salmon. Also, it is more resistance to disease factors than other fish species especially with intensive culturing (Salinas et al., 2006). Intensive culture of tilapia is an important factor for optimizing fish production with considering both feed quality and stocking density. Furthermore, stocking density is an important indicator to determine the economic impact of the used production system (Aksungur et al., 2007). Intensive fish culture makes highly stressful conditions for fish that further holds the immune activity and outbreak of diseases (Kumari and Sahoo, 2005). However, the disease conditions are restricting factor in tilapia culture production. It is costly at different tilapia farms and hatcheries to use a lot of antibiotics, vaccines, and chemotherapeutic agents as immunostimulants to resistance infections of harmful organisms. Immunostimulants by their broad-spectrum function may be a valuable and more effective trend to health management for fish infections controlling and therefore can be improve the production of fish culture (Nya and Austin, 2009).

Feed additives especially, immunostimulants could improve the immunity of cultured fish species, digestion rates, obtains the preferable flesh and skin pigmentation, enhancing the organoleptic features of the cultured fish product without adverse effects on both the farmed fish species and its environment (Ajiboye et al., 2012). Beside, the immune system of aquatic organisms, such as tilapia fish, is subjected to undesirable effects by periodic or unexpected changes of their environment. Garlic is one of the Liliaceae family used as a spice and also in medical proposes. Many studies were performed on different forms of garlic extracts as aqueous, ethanol and dried powder (Shin and Kim, 2004). Chemical analysis of a garlic explained that, organo sulfur compounds were included such as allicin, ajoene, S-allylcysteine, diallyl disulfide, S sulfoxide and S-allylcysteine. Also, after garlic cloves crushing, chemical substances 
as odorless compound alliinwhichis transformed to allicin, by the allinase enzyme. Moreover, it contains some vitamins and macro minerals and trace elements (selenium \& germanium). A. sativum may be used as hypolipidemic, antimicrobial, antihypertensive, hepato protective and insecticidal. Also, it can decrease serum cholesterol levels and improved blood clotting time (Gabor et al., 2012).

So, the present study to evaluate the garlic (Allium sativum) efficiency in improving growth performance, body composition, blood components and health of Nile tilapia O. niloticus fingerlings raised under different stocking densities.

\section{MATERIALS AND METHODS}

This investigation was carried out at the Wet Laboratory, Department of Animal Production, Faculty of Agriculture, Zagazig University, Egypt. Nile tilapia (Oreochromis niloticus) fingerlings were gifted from the Central Laboratory for Aquaculture Research at Abbassa, Abou-Hammad, Sharkia, Egypt. The experiment lasted for 12 weeks (after acclamyzation period for three weeks in Wet. Lab.)

\section{Experimental fish and diets}

The experimental fish were randomly distributed into 18 glass aquariums $\left(35 \times 40 \times 70 \mathrm{~cm} ; 751^{3}\right)$, representing to 6 treatments ( 3 replicates per treatment).

Using a factorial design ( $2 \times 3)$, a total of two hundred and seventy Nile tilapia fingerlings with initial body weight of $5.06 \mathrm{~g}$ were randomly separately into 2 main experimental groups, The $1^{\text {st }}$ group was stocked at a rate of 10 fish/aquarium and the $2^{\text {nd }}$ one was stocked at a rate of 20 fish/aquarium. Each main group was divided into 3 sub-groups; the $1^{\text {st }}$ was fed on a diet without supplementation with garlic, the $2^{\text {nd }}$ and $3^{\text {rd }}$ groups were fed on diets supplemented with 10 and $20 \mathrm{~g}$ garlic/ $\mathrm{kg}$ diet, respectively. Fish in all groups were kept under the same optimum conditions, water quality and an artificial photo period equal to natural light/darkness period (12h light: $12 \mathrm{~h}$ darkness).

Fish were weighed to the nearest $0.1 \mathrm{~g}$ at the beginning of the experiment and fed the experimental diets 6 days every week at a level of $5 \%$ of live body weight during the whole experimental period. Feed amount was re-adjusted after weighing according the new weight biweekly and the amount of feed given was adjusted in accordingly on basis of the new biomass. Fresh tap water was stored in fiberglass tanks for $24 \mathrm{~h}$ under aeration for dechlorination and half of all aquaria were replaced every two days. Air stones were used for aerating the aquaria water. Feces were disinterested daily by siphoning.

The experimental diets consisted of fish meal (72\%), soybean meal (44\%), yellow corn. rice bran, wheat bran, soybean oil, vitamins and minerals. Experimental diet contained about $30 \%$ crude protein and $429 \mathrm{kcal} / \mathrm{kg}$ as gross energy (Table 1). Experimental fish in all groups were fed at a rate of 5\% of the daily body weight for 12 weeks, respectively. The feed amount was given six days a week for 12 weeks at three times daily $(900,1200$ and 1500) in equal proportions. The fish were weighed weekly and feed intake was adjusted on the basis of the current weight.

\section{Water quality}

Water temperature and dissolved oxygen were measured every other day using HI 9146 (Oxygen and Temperature Meter, Hanna Instruments, Romania). Water quality parameters were measured twice weekly before replacing the water in the aquarium during the experimental period. Total ammonium, nitrite and $\mathrm{pH}$ levels were measured using the Hach kit model HI 83205 (Multipurameter Bench Photometer, Hanna Instruments, Romania).

\section{Growth performance}

Daily live body weight gain was calculated by subtracting the two successive live weights at different experimental periods. The specific growth rate was calculated according to Laird and Needham (1988) by the following equation: [Log final mean body weight - Log initial mean body weight] /time intervals (days) $\times 100$. The feed conversion ratio $(\mathrm{FCR})$ is expressed as the proportion of dry food required per unit live weight gain of fish according to the following equation: FCR = feed intake (g)/ weight gain (g). Also, Survival rate (SR) was calculated by the following equation: SR\% = end number of the live fish/the beginning number of the fish $\mathrm{x} 100$.

Fish samples were randomly taken from each aquarium for chemical analysis at the end of experimental period. Whole fish bodies were analyzed for moisture, total protein, ether extract and ash 
contents according to the methods described by AOAC (1995).

Gross energy (GE) stuffing of the experimental diet and fish samples were calculated by using factors of 5.65, 9.45 and $4.22 \mathrm{kcal} / \mathrm{g}$ of protein, lipid and carbohydrates, respectively (NRC, 1993).

The body composition as crude protein and ether extract content of the experimental tilapia fish were determined using Kjeldahl and Soxhlet apparatus.

Table (1): Ingredients and proximate analysis of experimental diet.

\begin{tabular}{|c|c|}
\hline Ingredient & D1(Control diet) \\
\hline \multicolumn{2}{|l|}{ Ingredients \% } \\
\hline Fish meal $(72 \%)$ & 12 \\
\hline Soybean meal (44\%) & 37 \\
\hline Yellow corn & 28 \\
\hline Rice bran & 10 \\
\hline Wheat bran & 10 \\
\hline Soybean oil & 2 \\
\hline Vitamins & 0.5 \\
\hline Minerals & 0.5 \\
\hline Total & 100 \\
\hline \multicolumn{2}{|c|}{ Chemical composition(\% DM) } \\
\hline Dry matter & 89.87 \\
\hline Organic matter & 83.91 \\
\hline Crude protein & 30.29 \\
\hline Ether extract & 5.03 \\
\hline Crude fiber & 6.70 \\
\hline Crude ash & 5.96 \\
\hline Nitrogen Free Extract ${ }^{1}$ & 43.13 \\
\hline \multicolumn{2}{|l|}{ Calculated energy value } \\
\hline $\mathrm{GE}(\mathrm{Kcal} / \mathrm{kg})^{2}$ & 428.98 \\
\hline $\mathrm{DE}(\mathrm{Kcal} / \mathrm{Kg})^{3}$ & 321.74 \\
\hline $\mathrm{CP} / \mathrm{GE}(\mathrm{mg} / \mathrm{Kcal})^{4}$ & 706.08 \\
\hline \multicolumn{2}{|c|}{${ }^{1}$ Nitrogen Free Extract was calculated by the difference: $100-($ moisture + protein + lipid + ash + Crude fiber $)$} \\
\hline \multicolumn{2}{|c|}{$\begin{array}{l}{ }^{2} \text { GE (Gross energy) was calculated according to NRC (1993) by using factors of 5.65, } 9.45 \text { and } 4.22 \mathrm{~K} \text { cal per gram } \\
\text { of protein, lipid and carbohydrate, respectively. }\end{array}$} \\
\hline $\begin{array}{l}{ }^{3} \text { DE (Digestible energy) } \\
\text { energy according to Heph }\end{array}$ & of 0.75 to convert gross energy to digestible \\
\hline
\end{tabular}

\section{Blood analysis}

At the end of the experiment, five fish from each treatment were taken randomly for blood analysis. Heparinized syringes were used to collect the blood samples from the caudal vein. Samples were used to calculate the hemoglobin $(\mathrm{Hb})$ content using a commercial kit (Diamond Diagnostic, Egypt), was measured according to Stoskopf (1993). Total erythrocyte (RBCs), platelets and leukocyte (WBCs) counts were determined by using an Ao Bright-Line Haemocytometer (Neubauer improved, Precicolor HBG, Germany) according to the methods described by Jain (1993). Other blood samples were collected without the addition of anticoagulants and then centrifuged at $4000 \mathrm{rpm}$ for $20 \mathrm{~min}$ to make separation of plasma for determining plasma total protein (Tietz, 1990). The activity of alanine aminotransferase (ALT) and aspartate aminotransferase (AST) were estimated according to Young (1990).

\section{Disease challenge test}

As a disease challenge, A. hydrophila $(0.5 \mathrm{ml}$ of culture suspension of pathogenic Aeromonas hydrophila containing $10^{8}$ bacteria $\mathrm{ml}^{-1}$ ) was injected I/P to20 fish/treatment (Aly et al. 2008). Inoculated fish were observed daily for 10 days and mortalities were recorded. The relative level of protection (RLP) among the challenged fish was determined according to Ruangroupan et al. (1986): RLP \% $=100-$ (treatment mortality \%/control mortality $\%) \times 100$. 


\section{Statistical analysis:}

Analysis of variance for data was accomplished using the SAS General Liner Models Procedure (SAS, 2002). The effects of fish stocking density and garlic supplementation were statistically analyzed by factorial analysis of variance (2X3) (Snedecor and Cochran 1982) according the following statistical model:

$$
Y_{i j k}=\mu+D_{i}+G_{j}+D G_{i j}+e_{i j k},
$$

Where: $Y_{i j k}$ is an observation, $\mu$ is the overall mean, $D_{i}$ is the fixed effect of fish stocking density $(i=1 \ldots 2), G_{j}$ is the fixed effect of dietary garlic supplementation $(j=1 \ldots 3), D_{i j}$ is the interaction effect of fish stocking density and dietary garlic supplementation treatments and $\mathrm{e}_{\mathrm{ijk}}$ is random error. Means were tested for significant differences by using Duncan's multiple range test (Duncan, 1955). All percentage and ratios were transformed to arc sin values previous to analysis (Zar 1984).

\section{RESULTS AND DISCUSSION}

\section{Water quality:}

During the whole of experimental period, there were no observed differences in all water quality parameters tested in the all experimental groups. Water quality criteria were suitable for rearing Nile tilapia $O$. niloticus fingerlings. Water temperature, oxygen, $\mathrm{pH}$, total ammonia and nitrite (overall mean) were $28.01 \pm 0.050{ }^{\circ} \mathrm{C}, 8.100 \pm 0.032 \mathrm{mg} / \mathrm{L}, 7.55 \pm 0.07,0.27 \pm 0.02 \mathrm{mg} / \mathrm{L}, 0.08 \pm 0.006 \mathrm{mg} / \mathrm{L}$, respectively. Ranges of water quality parameters were lying within the acceptable ranges required for normal growth of tilapia as mentioned by Boyd (1990).

\section{Growth performance}

Effect of garlic supplementation with different stoking densities and their interaction on growth parameters of Nile tilapia is presented in Table (2).

The current results showed that, supplementary garlic significantly $(\mathrm{P}<0.05)$ increased growth indices of the experimental fish. The higher increase of FW, DWG, SGR and SR were detected by garlic supplementation at $20 \mathrm{~g} / \mathrm{kg} \operatorname{diet}(46.86,0.50 \mathrm{~g} / \mathrm{day}, 1.15$ and $98.33 \%)$. Also, the supplementation of garlic especially with $20 \mathrm{~g} / \mathrm{kg}$ diet enhanced daily feed intake and feed conversion rate (0.93 $\mathrm{g} /$ fish and 1.87). Low stocking density rate had significant $(\mathrm{p}<0.05)$ higher values of FW, DWG, SGR, daily feed intake and lower feed conversion rate compared with high density stocking rate. Survival rate and growth performance were affected negatively by fish stocking densities. There were some reasons for growth inhabitation with high stocking density of experimental fish as the high competition and low space among the fish. The present results are agreement with Mollah et al. (1985) who obtained larger size and higher survival rate of Clarias macrocephalu. On the other hand, the interaction of dietary garlic supplementation and fish stocking rate had no significant $(\mathrm{P} \geq 0.05)$ influence on growth performance of tested fish except for FW and DWG. In general, low density fish fed diets supplemented with agarlic at $20 \mathrm{~g} / \mathrm{kg}$ diet had the preferable procedures of growth performance compared to other experimental fish groups. In agreement with the present results Soltan and El-Laithy (2008) explained that including garlic in growing $O$. niloticus diets enhanced significantly FW, FBL, WG and SGR. Also, Shalaby et al. (2006) reported that the addition of garlic in Nile tilapia diets at different levels $(10,20,30$ and $40 \mathrm{~g} / \mathrm{kg}$ diet) improved significantly FW and SGR especially with higher addition levels. The act of garlic as growth promoter may be return to the increase of glucose inflow into body tissues and its thyroid like function and also bioactive sulfur components in garlic as allin, diallylsulphides and allicin have antimicrobial activity which enhance immunity and therefore improve growth (Ibrahim et al., 2004).

\section{Body composition}

Stocking rate, supplementary garlic and their interaction effect on body composition of Nile tilapia are shown in Table (3).

Data of table (3) explained that, the stocking rate and garlic addition significantly $(\mathrm{P}<0.05)$ affected on whole body composition parameters as moisture, crude protein ether extract and ash of experimental fish groups. The lower moisture with higher $\mathrm{CP}, \mathrm{EE}$ and $\mathrm{ASH}$ of whole body composition were obtained by low stocking density rate of tested fish. Moniruzzaman et al. (2015) demonstrated that high stock rate of mono sex tilapia (Oreochromis niloticus L.) at $125 \mathrm{fish} / \mathrm{m}^{3}$ contained significantly low body composition of lipid and carbohydrate contents compared to other low rate groups $\left(50.75\right.$ and $\left.100 \mathrm{fish} / \mathrm{m}^{3}\right)$. The 
explanation of this might be return to over use of body energy for maintenance and growth during the experimental period. Supplemented garlic at $10 \mathrm{~g} / \mathrm{kg}$ diet had the higher CP, EE and ASH of fish body composition (12.74, 4.09 and 3.38\%, respectively). While, $20 \mathrm{~g} / \mathrm{kg}$ diet garlic level had lower ( $\mathrm{P}>0.05)$ $\mathrm{CP}$, EE and ASH compared to control one. The interaction procedures referred that, the higher body composition $\mathrm{CP}$ with moderate $\mathrm{EE}$ of tested fish were detected by low density rate of rearing fish fed diets supplemented with $10 \mathrm{~g}$ garlic/kg diet (122.88 and 3.92\%). Abdel-Hakim et al., (2010) referred that

Table (2). Effect of fish stocking density, dietary garlic supplementation and their interaction on growth performance of Nile tilapia.

\begin{tabular}{|c|c|c|c|c|c|c|c|}
\hline Item & $\begin{array}{l}\text { Initial } \\
\text { weight } \\
\text { (g) }\end{array}$ & $\begin{array}{c}\text { Final } \\
\text { weight, } \\
\text { FW } \\
\text { (g/fish) }\end{array}$ & $\begin{array}{l}\text { Daily } \\
\text { weight } \\
\text { gain, } \\
\text { DWG } \\
\text { (g/fish) }\end{array}$ & 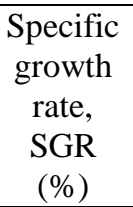 & $\begin{array}{l}\text { Daily Feed } \\
\text { intake } \\
\text { (g/fish) }\end{array}$ & $\begin{array}{c}\text { Feed } \\
\text { conversion } \\
\text { (g food/g } \\
\text { gain) }\end{array}$ & $\begin{array}{c}\text { Survival } \\
\text { rate, SR } \\
(\%)\end{array}$ \\
\hline \multicolumn{8}{|c|}{ Effect of stocking density } \\
\hline Low stocking & 5.05 & 45.14 & 0.48 & 1.13 & 0.90 & 1.897 & 96.67 \\
\hline density $\left(D_{1)}\right.$ & \pm 0.01 & \pm 1.75 & \pm 0.021 & \pm 0.020 & \pm 0.023 & \pm 0.038 & \pm 1.67 \\
\hline High stocking & 5.08 & 39.63 & 0.41 & 1.06 & 0.83 & 2.037 & 94.44 \\
\hline density $\left(D_{2}\right)$ & \pm 0.01 & \pm 1.33 & \pm 0.016 & \pm 0.018 & \pm 0.019 & \pm 0.035 & \pm 1.55 \\
\hline Significance & NS & ** & ** & ** & $* *$ & ** & NS \\
\hline \multicolumn{8}{|c|}{ Effect of dietary garlic supplementation } \\
\hline & 5.06 & 36.58 & 0.38 & 1.02 & 0.79 & 2.105 & 91.67 \\
\hline Control $\left(\mathrm{T}_{1}\right)$ & \pm 0.01 & $\pm 0.94^{\mathrm{c}}$ & $\pm 0.012^{\mathrm{c}}$ & $\pm 0.014^{\mathrm{c}}$ & $\pm 0.012^{\mathrm{c}}$ & $\pm 0.031^{\mathrm{a}}$ & $\pm 2.11^{\mathrm{b}}$ \\
\hline $10 \mathrm{~g}$ garlic $/ \mathrm{kg}$ & 5.07 & 43.73 & 0.46 & 1.12 & 0.88 & 1.925 & 96.67 \\
\hline $\operatorname{diet}\left(\mathrm{T}_{2}\right)$ & \pm 0.01 & $\pm 1.22^{\mathrm{b}}$ & $\pm 0.015^{\mathrm{b}}$ & $\pm 0.014^{\mathrm{b}}$ & $\pm 0.016^{\mathrm{b}}$ & $\pm 0.030^{\mathrm{b}}$ & $\pm 1.67^{\mathrm{ab}}$ \\
\hline $20 \mathrm{~g}$ garlic / & 5.07 & 46.86 & 0.50 & 1.15 & 0.93 & 1.870 & 98.33 \\
\hline $\mathrm{kg} \operatorname{diet}\left(\mathrm{T}_{3}\right)$ & \pm 0.02 & $\pm 1.63^{\mathrm{a}}$ & $\pm 0.020^{\mathrm{a}}$ & $\pm 0.020^{\mathrm{a}}$ & $\pm 0.018^{\mathrm{a}}$ & $\pm 0.036^{\mathrm{c}}$ & $\pm 1.05^{\mathrm{a}}$ \\
\hline Significance & NS & ** & $* *$ & ** & ** & ** & * \\
\hline \multicolumn{8}{|c|}{ The interaction effect of stocking density and dietary garlic supplementation } \\
\hline \multirow{3}{*}{$\mathrm{D}_{1} * \mathrm{~T}_{1}$} & 5.03 & 38.62 & 0.40 & 1.05 & 0.81 & 2.040 & 93.33 \\
\hline & \pm 0.01 & $\pm 0.29^{\mathrm{d}}$ & $\pm 0.006^{\mathrm{e}}$ & \pm 0.003 & \pm 0.003 & \pm 0.017 & \pm 3.33 \\
\hline & 5.06 & 46.38 & 0.49 & 1.15 & 0.92 & 1.860 & 96.67 \\
\hline \multirow{2}{*}{$\mathrm{D}_{1} * \mathrm{~T}_{2}$} & \pm 0.01 & $\pm 0.42^{\mathrm{b}}$ & $\pm 0.007^{\mathrm{b}}$ & \pm 0.003 & \pm 0.009 & \pm 0.010 & \pm 3.33 \\
\hline & 5.05 & 50.43 & 0.54 & 1.19 & 0.97 & 1.790 & 100.00 \\
\hline \multirow{2}{*}{$\mathrm{D}_{1} * \mathrm{~T}_{3}$} & \pm 0.03 & $\pm 0.60^{\mathrm{a}}$ & $\pm 0.006^{\mathrm{a}}$ & \pm 0.012 & \pm 0.007 & \pm 0.010 & \pm 0.00 \\
\hline & 5.08 & 34.55 & 0.35 & 0.99 & 0.76 & 2.170 & 90.00 \\
\hline \multirow[t]{2}{*}{$\mathrm{D}_{2} * \mathrm{~T}_{1}$} & \pm 0.01 & $\pm 0.47^{\mathrm{e}}$ & $\pm 0.006^{\mathrm{f}}$ & \pm 0.007 & \pm 0.009 & \pm 0.021 & \pm 2.89 \\
\hline & 5.07 & 41.07 & 0.43 & 1.08 & 0.85 & 1.990 & 96.67 \\
\hline \multirow[t]{2}{*}{$\mathrm{D}_{2} * \mathrm{~T}_{2}$} & \pm 0.01 & $\pm 0.43^{\mathrm{c}}$ & $\pm 0.006^{\mathrm{d}}$ & \pm 0.003 & \pm 0.006 & \pm 0.010 & \pm 1.67 \\
\hline & 5.08 & 43.28 & 0.45 & 1.10 & 0.89 & 1.950 & 96.67 \\
\hline $\mathrm{D}_{2} * \mathrm{~T}_{3}$ & \pm 0.02 & $\pm 0.34^{\mathrm{c}}$ & $\pm 0.003^{\mathrm{c}}$ & \pm 0.007 & \pm 0.007 & \pm 0.006 & \pm 1.67 \\
\hline Significance & NS & $* *$ & $* *$ & NS & NS & NS & NS \\
\hline
\end{tabular}

Means in the same column within each classification having different superscript letters were significantly different at $P<0.05$.

addition of fresh or dried garlic (Allium sativum) in O. niloticus diets had no significant effects on fish whole bodies moisture; DM and ash contents, while it released significant effects on the whole body protein and lipid compared to control group. In addition, Xiang and Liu (2002) observed that, the supplementation of $25-100 \mathrm{mg}$ garlic $/ \mathrm{kg}$ in C. barchypomum diets improve the body protein and decrease the crude lipid content of experimental fish. Results of Molly fish body compositions showed that including $5 \mathrm{~g} / \mathrm{kg}$ of garlic increased significantly whole body crude protein, while total lipid content was decreased significantly with the same levels of A. sativum. Moreover, Pour et al., (2014) showed that, the ash and moisture content of fish was not differed significantly by a garlic addition compared with control group. While, Ajiboye et al., (2016) explained that, the decrease in whole body lipid content of $T$. zillii fish may be return to the action of bioactive compounds in garlic which increases the excretion of acidic and neutral steroids that cause the lower cholesterol level in body composition of experimental fish. Also, they referred that, the significant $(\mathrm{P}<0.05)$ higher $\mathrm{CP}$ content of fish carcass could be due to higher 
content of palatable amino acids to experimental fish which resulting from activating intestinal proteases through allicin compound in a garlic.

Table (3): Effect of fish stocking density, dietary garlic supplementation and their interaction on fish body components.

\begin{tabular}{|c|c|c|c|c|}
\hline Item & Moisture \% & $\begin{array}{l}\text { Crude protein } \\
\%\end{array}$ & $\begin{array}{l}\text { Ether extract } \\
\%\end{array}$ & Ash \% \\
\hline \multicolumn{5}{|l|}{ Effect of stocking density } \\
\hline Low stocking density $\left(\mathrm{D}_{1)}\right.$ & $79.72 \pm 0.173$ & $12.60 \pm 0.091$ & $4.09 \pm 0.045$ & $3.38 \pm 0.028$ \\
\hline High stocking density $\left(\mathrm{D}_{2}\right)$ & $80.11 \pm 0.188$ & $12.24 \pm 0.107$ & $3.95 \pm 0.062$ & $3.20 \pm 0.026$ \\
\hline Significance & $* *$ & $* *$ & $* *$ & $* *$ \\
\hline \multicolumn{5}{|c|}{ Effect of dietary garlic supplementation } \\
\hline Control $\left(\mathrm{T}_{1}\right)$ & $79.68 \pm 0.084^{\mathrm{b}}$ & $12.37 \pm 0.088^{\mathrm{b}}$ & $4.13 \pm 0.033^{\mathrm{a}}$ & $3.26 \pm 0.028^{b}$ \\
\hline $10 \mathrm{~g} / \mathrm{kg}$ diet garlic $\left(\mathrm{T}_{2}\right)$ & $79.49 \pm 0.097^{\mathrm{b}}$ & $12.74 \pm 0.081^{\mathrm{a}}$ & $4.11 \pm 0.022^{\mathrm{a}}$ & $3.38 \pm 0.048^{\mathrm{a}}$ \\
\hline $20 \mathrm{~g} / \mathrm{kg}$ diet garlic $\left(\mathrm{T}_{3}\right)$ & $80.57 \pm 0.176^{\mathrm{a}}$ & $12.15 \pm 0.128^{\mathrm{c}}$ & $3.82 \pm 0.049^{\mathrm{b}}$ & $3.24 \pm 0.053^{b}$ \\
\hline Significance & $* *$ & $* *$ & $* *$ & $* *$ \\
\hline \multicolumn{5}{|c|}{ The interaction effect of stocking density and dietary garlic supplementation } \\
\hline $\mathrm{D}_{1} * \mathrm{~T}_{1}$ & $79.52 \pm 0.066$ & $12.55 \pm 0.002$ & $4.19 \pm 0.003$ & $3.32 \pm 0.006$ \\
\hline $\mathrm{D}_{1} * \mathrm{~T}_{2}$ & $79.33 \pm 0.139$ & $12.88 \pm 0.066$ & $4.15 \pm 0.030$ & $3.48 \pm 0.018$ \\
\hline $\mathrm{D}_{1} * \mathrm{~T}_{3}$ & $80.31 \pm 0.263$ & $12.37 \pm 0.171$ & $3.92 \pm 0.029$ & $3.35 \pm 0.040$ \\
\hline $\mathrm{D}_{2} * \mathrm{~T}_{1}$ & $79.85 \pm 0.052$ & $12.19 \pm 0.077$ & $4.07 \pm 0.044$ & $3.20 \pm 0.003$ \\
\hline $\mathrm{D}_{2} * \mathrm{~T}_{2}$ & $79.65 \pm 0.048$ & $12.61 \pm 0.102$ & $4.08 \pm 0.014$ & $3.28 \pm 0.037$ \\
\hline $\mathrm{D}_{2} * \mathrm{~T}_{3}$ & $80.84 \pm 0.120$ & $11.93 \pm 0.063$ & $3.72 \pm 0.036$ & $3.13 \pm 0.016$ \\
\hline Significance & NS & NS & NS & NS \\
\hline
\end{tabular}

Means in the same column within each classification having different superscript letters were significantly different at $P<0.05$.

\section{Blood parameters}

Influence of stocking rate, garlic supplementation and their interaction on blood indices of experimental fish is explained in Table (4).

There were significant $(\mathrm{p}<0.05)$ higher increase by lower fish stocking density in blood parameters TWBC, TRBC concentration and Hb level and lower ( $\mathrm{p}<0.05)$ effects on ALT, TP, GLB concentration. Blood AST and ALB concentration were not significantly ( $p>0.05)$ differed by fish stocking density. Also, the higher garlic supplementation increased significantly $(\mathrm{p}<0.05)$ blood TWBC and TRBC concentration and significantly $(\mathrm{p}<0.05)$ decreased liver AST and ALT activity without significant effect on $\mathrm{Hb}, \mathrm{TP}$, albumin and globulin parameters. On the contrary, the garlic supplementation had no significant effect on blood TP, ALB, GLB concentration and Hb percentage. Kpundeh et al. (2013) found that, hematoogical parameters of Tilapia juveniles contained RBC, WBC, hemoglobin, hematocrit and platelet decreased as stocking rate increased, while indices of liver activity as AST and ALT levels were increased significantly. Ayyat et al. (2011) found that, blood total protein, albumin and ALT were decreased in Nile tilapia fish groups reared at high stocking density compared with low stocking density $\left(200 \mathrm{Vs} .100 \mathrm{fish} / \mathrm{m}^{3}\right)$. The interaction effect appeared no significant ( $\left.\mathrm{p}>0.05\right)$ influence on all estimated blood procedures in this study. In general, the higher immunity indices as blood TWBC, TRBC concentration and $\mathrm{Hb}$ level were obtained by low stocking rate of fish group fed diet supplemented with $20 \mathrm{~g}$ garlic/kg diet $(26.65,3.22$ and $6.00 \%$, respectively). The inclusion of haematological parameters may be giving valuable information for fishery biologists in the estimation of fish health (Blaxhall, 1972). The current results are approved with Iranloye (2002) and Sahu et al. (2007) who explained that, the improvement in RBC, WBC, and other blood cells including neutrophils, lymphocytes and monocytes counts with garlic addition may due to the garlic's anti-infection properties. Furthermore, garlic can be useful for controlling the pathogens, especially bacteria and fungi diseases which improves the welfare of fish (Corzo-Martinez et al., 2007). Hegazi, (2010) pointed that, AST or ALT are not a liver-specific enzyme but, it may be found both in hepatocytes and muscle cells, kidneys, and also may be found in the gills. They are commonly used to evaluate the liver function as hepatocellular diseases procedure. In the present experiment the preferable levels of AST and ALT enzymes were obtained by high level of garlic supplementation while, stocking rate had a slight effect on both liver enzymes. 
Table (4): Effect of fish stocking density, dietary garlic supplementation and their interaction on blood components of Nile tilapia.

\begin{tabular}{|c|c|c|c|c|c|c|c|c|}
\hline Item & $\begin{array}{c}\text { TWBC } \\
\left(10^{6} \mathrm{~mm}^{-3}\right)\end{array}$ & $\begin{array}{c}\text { TRBC } \\
\left(1^{6} \mathrm{~mm}^{-3}\right)\end{array}$ & $\mathrm{Hb}(\%)$ & $\begin{array}{l}\text { AST } \\
(\mathrm{U} / \mathrm{dl})\end{array}$ & $\begin{array}{c}\text { ALT } \\
(\mathrm{U} / \mathrm{dl})\end{array}$ & $\begin{array}{c}\text { Total } \\
\text { protein, } \\
(\mathrm{g} / \mathrm{dl})\end{array}$ & $\begin{array}{l}\text { Albumin } \\
(\mathrm{g} / \mathrm{dl})\end{array}$ & $\begin{array}{c}\text { Globulin } \\
(\mathrm{g} / \mathrm{dl})\end{array}$ \\
\hline \multicolumn{9}{|c|}{ Effect of stocking density } \\
\hline Low stocking & $24.96^{\circ}$ & 3.03 & 5.74 & 28.33 & 15.14 & 4.77 & 3.19 & 1.58 \\
\hline density $\left(D_{1}\right)$ & \pm 0.66 & \pm 0.05 & \pm 0.11 & \pm 1.31 & \pm 0.68 & \pm 0.25 & \pm 0.08 & \pm 0.21 \\
\hline High stocking & 23.79 & 2.97 & 5.63 & 29.28 & 16.52 & 5.05 & 3.36 & 1.70 \\
\hline density $\left(D_{2}\right)$ & \pm 0.44 & \pm 0.04 & \pm 0.13 & \pm 1.55 & \pm 0.52 & \pm 0.20 & \pm 0.09 & \pm 0.18 \\
\hline Significance & $*$ & $*$ & $* *$ & NS & $* *$ & $* *$ & NS & $* *$ \\
\hline \multicolumn{9}{|c|}{ Effect of dietary garlic supplementation } \\
\hline & 22.65 & 2.85 & 5.33 & 34.17 & 17.91 & 5.65 & 3.47 & 2.19 \\
\hline Control $\left(\mathrm{T}_{1}\right)$ & $\pm 0.60^{\mathrm{b}}$ & $\pm 0.01^{\mathrm{c}}$ & \pm 0.10 & $\pm 0.90^{\mathrm{a}}$ & $\pm 0.47^{\mathrm{a}}$ & \pm 0.17 & \pm 0.09 & \pm 0.20 \\
\hline $10 \mathrm{~g} / \mathrm{kg}$ diet & 24.83 & 3.01 & 5.77 & 26.75 & 15.18 & 4.76 & 3.25 & 1.51 \\
\hline garlic $\left(\mathrm{T}_{2}\right)$ & $\pm 0.35^{\mathrm{a}}$ & $\pm 0.02^{\mathrm{b}}$ & \pm 0.10 & $\pm 0.48^{\mathrm{b}}$ & $\pm 0.55^{\mathrm{b}}$ & \pm 0.11 & \pm 0.11 & \pm 0.13 \\
\hline $20 \mathrm{~g} / \mathrm{kg}$ diet & 25.66 & 3.14 & 5.98 & 25.50 & 14.39 & 4.32 & 3.10 & 1.22 \\
\hline garlic $\left(\mathrm{T}_{3}\right)$ & $\pm 0.50^{\mathrm{a}}$ & $\pm 0.04^{\mathrm{a}}$ & \pm 0.09 & $\pm 0.50^{\mathrm{b}}$ & $\pm 0.39^{\mathrm{b}}$ & \pm 0.17 & \pm 0.09 & \pm 0.16 \\
\hline Significance & $* *$ & $* *$ & NS & $* *$ & $* *$ & NS & NS & NS \\
\hline \multicolumn{9}{|c|}{ The interaction effect of stocking density and dietary garlic supplementation } \\
\hline \multirow{3}{*}{$\mathrm{D}_{1} * \mathrm{~T}_{1}$} & 23.00 & 2.87 & 5.38 & 33.00 & 17.57 & 5.57 & 3.38 & 2.18 \\
\hline & \pm 1.15 & \pm 0.02 & \pm 0.10 & \pm 1.53 & \pm 0.70 & \pm 0.32 & \pm 0.09 & \pm 0.31 \\
\hline & 25.23 & 3.02 & 5.85 & 26.67 & 14.17 & 4.67 & 3.18 & 1.48 \\
\hline \multirow[t]{2}{*}{$\mathrm{D}_{1} * \mathrm{~T}_{2}$} & \pm 0.50 & \pm 0.03 & \pm 0.14 & \pm 0.88 & \pm 0.60 & \pm 0.19 & \pm 0.15 & \pm 0.29 \\
\hline & 26.65 & 3.22 & 6.00 & 25.33 & 13.68 & 4.07 & 3.00 & 1.07 \\
\hline \multirow{2}{*}{$\mathrm{D}_{1} * \mathrm{~T}_{3}$} & \pm 0.44 & \pm 0.03 & \pm 0.15 & \pm 0.88 & \pm 0.41 & \pm 0.21 & \pm 0.10 & \pm 0.19 \\
\hline & 22.30 & 2.83 & 5.27 & 35.33 & 18.25 & 5.74 & 3.55 & 2.19 \\
\hline \multirow[t]{2}{*}{$\mathrm{D}_{2} * \mathrm{~T}_{1}$} & \pm 0.60 & \pm 0.02 & \pm 0.19 & \pm 0.60 & \pm 0.72 & \pm 0.19 & \pm 0.15 & \pm 0.33 \\
\hline & 24.42 & 3.00 & 5.68 & 26.83 & 16.20 & 4.85 & 3.32 & 1.53 \\
\hline \multirow{2}{*}{$\mathrm{D}_{2} * \mathrm{~T}_{2}$} & \pm 0.42 & \pm 0.03 & \pm 0.16 & \pm 0.60 & \pm 0.35 & \pm 0.13 & \pm 0.18 & \pm 0.04 \\
\hline & 24.67 & 3.07 & 5.95 & 25.67 & 15.10 & 4.57 & 3.20 & 1.37 \\
\hline $\mathrm{D}_{2} * \mathrm{~T}_{3}$ & \pm 0.28 & \pm 0.04 & \pm 0.13 & \pm 0.67 & \pm 0.32 & \pm 0.17 & \pm 0.14 & \pm 0.27 \\
\hline Significance & NS & NS & NS & NS & NS & NS & NS & NS \\
\hline
\end{tabular}

\section{Challenge test}

The mortality rate after the Aeromonas hydrophila challenge was higher in the control fish group than in the fish groups fed diets supplemented with garlic (Table 5).

Table (5): Relative level of protection (RLP) of Oreochromis niloticus at the end of the experimental period after dietary garlic treatment.

\begin{tabular}{lccccc}
\hline Fish group & $\begin{array}{c}\text { Total } \\
\text { number }\end{array}$ & $\begin{array}{c}\text { The number of } \\
\text { dead fish }\end{array}$ & $\begin{array}{c}\text { Survival } \\
\text { rate, } \%\end{array}$ & $\begin{array}{c}\text { Mortality } \\
\text { rate, } \%\end{array}$ & RLP, \% \\
\hline Dietary garlic supplementation & 20 & 4 & 80 & 20 & 0 \\
Control diet $\left(\mathrm{T}_{1)}\right.$ & 20 & 1 & 95 & 5 & 75 \\
$10 \mathrm{~g} / \mathrm{kg}$ diet garlic $\left(\mathrm{T}_{2}\right)$ & 20 & 0 & 100 & 0 & 100 \\
$20 \mathrm{~g} / \mathrm{kg}$ diet garlic $\left(\mathrm{T}_{3}\right)$ & & & & & \\
\hline
\end{tabular}

With increasing dietary garlic supplementation, the relative levels of protection were increased whereas the highest value in RLP (100\%) was recorded with $20 \mathrm{~g}$ garlic/kg diet followed by $10 \mathrm{~g} / \mathrm{kg}$ diet (75\%). Many defense mechanisms activated by garlic counteract the challenge infection including the production of superoxide anions against the A. hydrophila infection. It has been found that the aqueous extract of raw garlic and dried powder scavenge hydroxyl radicals (Yang et al, 1993 and Kim et al, 2001), and superoxide anions (Kim et al., 2001). 


\section{CONCLUSION}

It was concluded that garlic, Allium sativum could be use to enhance the health and growth performance with high stocking density of Nile tilapia, Oreochromis niloticus fingerlings.

\section{REFERENCES}

Abdel-Hakim, N.F., M.E.L. Mohamed, A.M.AA.AL-Desoki and M.A. Ahmed (2010). Effect of fresh or dried garlic as a natural feed supplement on growth performance and nutrients utilization of the Nile Tilapia (Oreochromisniloticus).Egypt J. Aquat. Biol. \& Fish., 14(2): 19-38. 9.

Ajiboye, O.O., A.F. Yakubu, J.O. Simpa and S.A. Balogun (2016). Effect of Garlic- Supplemented Diets on Growth Response, Survival,Nutrient Utilization and Body Composition of Monosex Tilapia zillii. World Journal of Fish and Marine Sciences 8 (2): 115-122.

Ajiboye, O.O., A.F. Yakubu and T.E. Adams (2012). A perspective on the ingestion and nutritional effects of feed additives in farmed fish species. World Journal of Fish and Marine Sciences, 4(1): 87101.

Aksungur N., M. Aksungur, B. Akbulut and I. Kutlu (2007). Effects of stocking density on growth performance, survival and food conversion ratio of Turbot (Psetta maxima) in the net cages on the southeastern coast of the Black Sea. Turk J Fish Aquat Sci 7: 147-152.

Aly, S. M.; Y. A. G Ahmed; A. A. A. Ghareeb and M. F. Mohamed (2008). Studies on Bacillus subtilis and Lactobacillus acidophilus, as potential probiotics, on the immune response and resistance of Tilapia nilotica (Oreochromis niloticus) to challenge infections. Fish Shellfish Immunol. 25:128-136.

AOAC (1995). Official Methods of Analysis of the Association of Official Analytical Chemists, 14th. AOAC, Arlington, 3413 pp.

Ayyat, M. S., H.I. EL-Marakby and S. Shara (2011). Effect of Dietary Protein Level, Stocking Density, and Dietary Pantothenic Acid Supplementation Rate on Performance and Blood Components of Nile Tilapia Oreochromisniloticus. Journal of Applied Aquaculture , 23:122-135.

Blaxhall, P. (1972). The hematological assessment of the health of freshwater fish: A review of selected literature. Journal of Fish Biology 4, 593-604.

Boyd, C. E. 1990. Water quality in ponds for aquaculture. Auburn University, Auburn, AL.Brace Jovanovich. Toronto, Canada.

Corzo-Martinez, M., N. Corzo and M. Villamiel, (2007). Biological properties of onions and garlic. Trends in Food Science and Technology 18, 609-625.

Gabor E.F., A. Şara, M. Benţea, C. Creţa and A. Baciu (2012). The effect of phytoadditive combination and growth performances and meat quality in rainbow trout (Oncorhychusmykiss), Journal of Animal Science and Biotechnology 45(2), 43-47.

Duncan, M.B., (1955). Multiple ranges and multiple F-tests. Biometrics, 11:1-42.

Hegazi, M.M. (2010). Metabolic consequences of chronic sublethal ammonia exposure at cellular and subcellular levels in Nile tilapia brain. Aquaculture, Amsterdan, 299:149-156.

Hepher, B.; I. C Liao; S. H. Cheng and C. S. Haseih (1983). Food utilization by red tilapia. Effect of diet composition, feeding level and temperature on utilization efficiency for maintenance and growth, Aquaculture, 32: 255 - 272.

Ibrahim, I.A., T.A. Elam, F.F. Mohamed, S.A. Awadalla and Y.I. Yousif (2004). Effect of onion and/or garlic as feed additives on growth performance and immunity in broiler muscovy ducks. The First Sci. Conf. Fac. Vet. Med., Moshtohor, Benha-RasSedr, Sep., pp: 1-4.

Iranloye, B.O. (2002). Effect of chronic garlic feeding on some haematological parameters. African Journal of Biomedical Research 5, 81-82.

Jain, N.C. (1993). Essential of veterinary hematology. copyrights by Lea and Febiger Philadelphia, USA.

Kim, K. M., S. B. Chun, M. S. Koo, W. J. Choi, T. W. Kim, Y. G. Kwon, H. T. Chung, T. R. Billiar and Y. M. Kim. (2001). Differential regulation of NO availability from macrophages and endothelial cells by the garlic component S-allyl cysteine. Free Radic. Biol. Med., 30, 747-756. 
Kpundeh, M. D., P. Xu, H. Yang, J. Qiang and J. He (2013). Stocking Densities and Chronic Zero Culture Water Exchange Stress' Effects on Biological Performances, Hematological and Serum Biochemical Indices of GIFT Tilapia Juveniles ( Oreochromisniloticus ). J Aquac Res Development , 4:5.

Kumari, J., and P.K. Sahoo (2005). Effects of cyclophosphamide on the immune system and disease resistance of Asian catfish (Clariasbatrachus). Fish \& Shellfish Immunology, 19:307-316.

Laird, L. and T. Needham (1988). Salmon and trout farming. Harwood, New York.

Mollah, M. F. A. (1985). Effects of stocking density and water dept $\mathrm{h}$ on the growth and survival of freshwater catfish, Clariasmacrocephalus Gunther larvae. Indian J. Fish., 1985, (32): 1-17.

Moniruzzaman, M, K. B. Uddin, S. Basak, Y. Mahmud, M. Zaher and S. C. Bai (2015). Effects of stocking density on growth, body composition, yield and economic returns of monosex tilapia (Oreochromisniloticus L.) under cage culture system in Kaptai Lake of Bangladesh. J Aquac Res Development, 6:8.

NRC (1993). Nutrition requirements of fish. National Research Council National academy press, Washington, D. C. 114 pp, USA.

Nya, E.J. and B. Austin (2009). Use of garlic, Allium sativum, to control Aeromonashydrophila infection in rainbow trout, Oncorhynchusmykiss (Walbaum). Journal of Fish Diseases 32, 963-970.

Pour, F., M. Maniat, A. Vahedasl and S. Ghayem (2014). Enhancement of growth performance and body composition in molly fish (Poeciliasphenops) associated with dietary intake of garlic (Allium sativum) . International Journal of Biosciences, 5: 8, 115-121.

Ruangroupan, L., T. Kitao and T. Yoshida (1986). Protective efficacy of Aeromonas hydrophila vaccines in Nile tilapia. Veterinary Immunology and Immunopathology 12(1-4):345-350.

Sahu, S., B.K. Das, B.K. Mishra, J. Pradhan and N. Sarangi (2007). Effects of Allium sativum on the immunity and survival of Labeorohita infected with Aeromonashydrophila. Journal of Applied Ichthyology 23, 80-86.

Salinas, I, P. Diaz-Rosales, A. Cuesta, J. Meseguer, M. Chabrillo'n, M. M. Igo and M.A. Esteban (2006). Effect of heat-inactivated fish and non-fish derived probiotics on the innate immune parameters of a teleost fish (Sparusaurat L.). Veterinary Immunology and Immunopathology, 111: 279-286.

SAS (2002). SAS Institute Inc., Cary, NC, USA. NOTE: SAS Proprietary Software Version 9.00 (TS M0).

Shalaby, A.M., Y.A. Khattab and M. Abdel Rahman (2006). Effects of garlic (Allium sativum) and chloramphenicol on growth performance, physiological parameters and survival of Nile tilapia (Oreochromisniloticus). Journal of Venom. Animal Toxins Incl. Tropical Disease, 12(2): 178.

Shin, S.H. and M.K. Kim (2004). Effect of dired powders or ethanol extracts of garlic flesh and peel on lipid metabolism and antithrombogenic capacity in 16-month-old rats. HangukYongyang Hakhoechi, allicin could activate intestinal proteases, which help to 37: 515-524.

Snedecor, G.W. and W.G. Cochran (1982). Statistical Methods. 7th ed. Iowa stat. Univ., Press. Ames. Iowa, U.S.A.

Soltan, M.A. and S.M. El-Laithy (2008). Effect of probiotics and some spices as feed additives on the performance and behaviour of the Nile tilapia, Oreochromis niloticus. Egyptian Journal of Aquatic Biology and Fisheries, 12(2): 63-80.

Stoskopf, M.K. (1993). Fish Medicine. pp. 113-131. Edited by M. K. Stoskopf. Saunders, Philadelphia.

Tietz, N.W. (1990). Clinical Guide to Laboratory Tests 2nd Ed. Philadelphia.

Xiang, X. and C.Z. Liu (2002). Effect of allicin on growth nd of Colossomabarchypomum. Fisheries Science and Technology Information, 29: 222-225.

Yang G. C., M. P. Yasaei and S. W. Page. (1993). Garlic as anti-oxidant and free radical scavenger. J. Food Drug Anal., 1: 357-364. Bermingham, Alabama, USA.

Young.D.S. (1990). Effects of drugs on clinical laboratory tests. Third Edition,AACC Press, Washington, D.C. $32(3): 30-33$.

Zar, J.H. (1984). Biostatistical analysis. Prentice-Hall Inc., Englewood Clifffs, New Jersey. 


\title{
تاثير اضافة الثوم للعلائق على اداء اصبعيات البلطى النيلى تحت معللين كثافة
}

\author{
همت كمال الدين محمود1 و عبد العزيز محم عبد العزيز الحايس 2

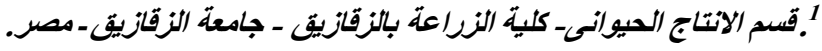 \\ 2قسم الانتاج الحيوانى كلية الزراعة بطنطا- جامعة طنطا- مصر.
}

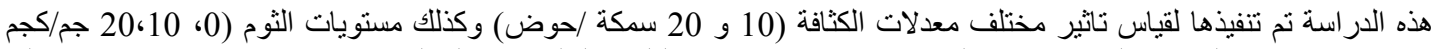

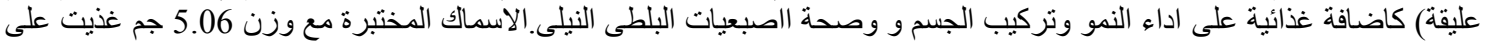

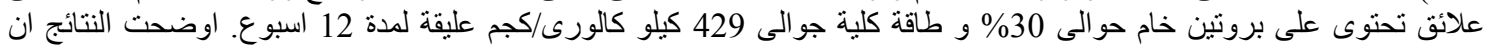

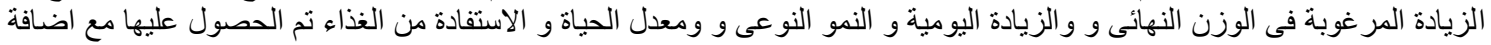

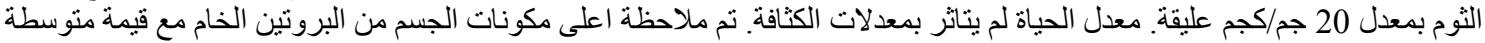

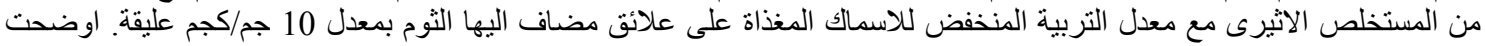

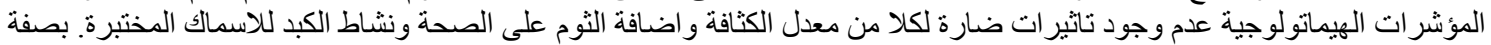

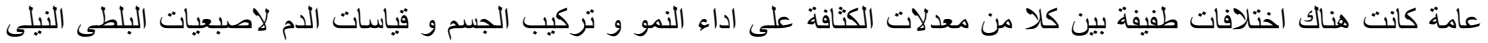

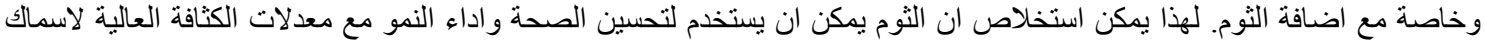

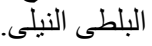

